Journal of

Health, Medicine and Nursing

(JHMN)

COLLEGE CONVERSION INTO COVID-19 QUARANTINE CENTER: READINESS OF PARENTS ON STUDENTS RESUMPTION TO COLLEGE

Rhoda Nchogu ${ }^{1}$ Dorcas Ngechu ${ }^{2}$ Caroline Mramba $^{3}$ Dominic Mutonga ${ }^{4}$ Jane Kima ${ }^{5}$

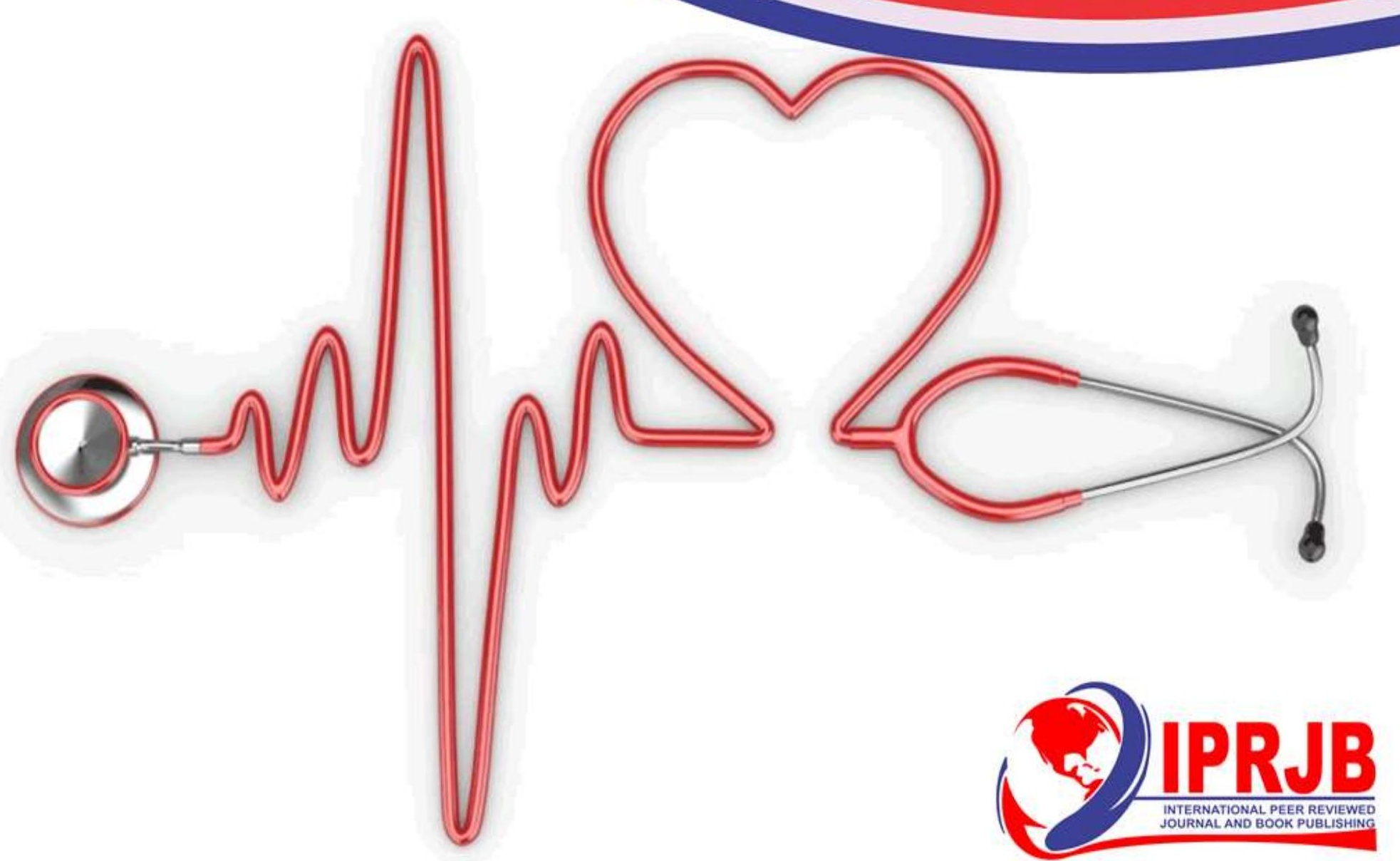


Journal of Health, Medicine and Nursing

ISSN 2520-4025 (Online)

Vol.5, Issue 5. No.4, pp 44- 50, 2020

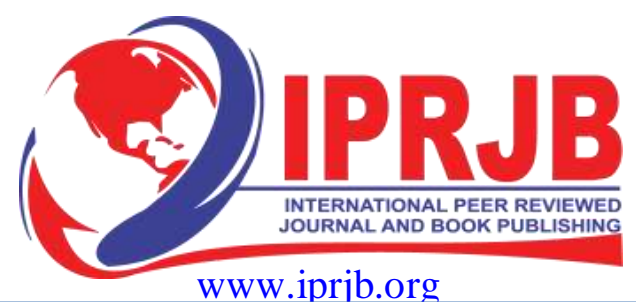

\title{
COLLEGE CONVERSION INTO COVID-19 QUARANTINE CENTER: READINESS OF PARENTS ON STUDENTS RESUMPTION TO COLLEGE
}

Rhoda Nchogu ${ }^{1}$ Dorcas Ngechu ${ }^{2}$ Caroline Mramba ${ }^{3}$ Dominic Mutonga ${ }^{4}$ Jane Kima $^{5}$

Affiliation:

1- Kenya Medical Training College (KMTC)

\author{
Corresponding Authors Emails \\ Rhoda Nchogu KMTC rnchogu@kmtc.ac.ke \\ Dorcas Ngechu KMTC dngechu@kmtc.ac.ke \\ Caroline Mramba KMTC cmramba@kmtc.ac.ke \\ Dominic Mutonga KMTC dmutonga@kmtc.ac.ke \\ Jane Kima KMTC jkima@kmtc.ac.ke
}

\begin{abstract}
Purpose: The aim of the study was to assess parents' readiness to allow students resume college after closure due to COVID-19.

Methodology: The study was descriptive cross-sectional design done at KMTC-Mombasa Campus. Participants (parents) were selected using multistage convenient random sampling method, where an assumption of each student having at least one parent was made. The total population of students is $850,10 \%$ of the student population was found to be a representative number for parents. $(0.1 \times 850), \mathrm{n}=85$ with a confidence level of $95 \%$. Response rate was $85.8 \%$ $(n=73)$. Data was obtained using interviewer administered questionnaires. Data analysis was done using SPSS and results presented using tables and narrations.
\end{abstract}

Results: $78 \%$ (57) parents were willing to allow students resume college immediately while 22 $\%$ of parents were reluctant to allow students go back to college. 78\% (57) parents were aware of the college being used as a quarantine center whereas $22 \%$ (16) were unaware. 92\% (67) guardians perceived the college as safe despite its use as a quarantine center, while $8 \%$ of the guardians termed the college unsafe. $8 \%$ (6) parents who perceived the college as unsafe were being reluctant to allow their children back to college. Perception of safety significantly affected the readiness to allow students back to college with a chi-square value of $(p=0.001)$.

Unique contribution to theory, practice, and policy This study investigated readiness of as parents as key stakeholders to allow students to resume college after it had been utilized as a quarantine centre during the COVID 19 pandemic. Readiness of parents to allow students resume studies in an institution used as a quarantine centre for clients suspected of having a highly infectious disease has not been examined in literature before especially in institutions of higher learning. The findings of this study are useful to policy makers and leaders in education sector as normalcy resumes and learning institutions are opened.

Key words: COVID-19, Kenya Medical Training College, Readiness, Mombasa, Quarantine Center, parents, student resume. 
Journal of Health, Medicine and Nursing

ISSN 2520-4025 (Online)

Vol.5, Issue 5. No.4, pp 44- 50, 2020

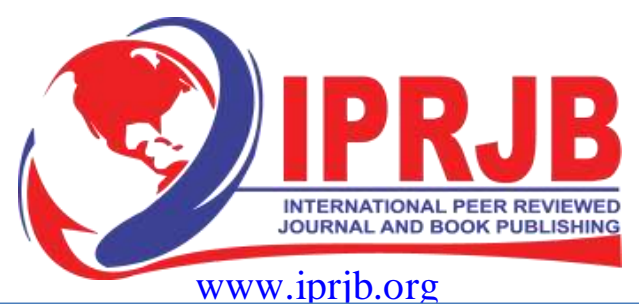

\subsection{INTRODUCTION}

COVID 19 was first detected in Wuhan China in November 2019.The World Health Organization declared the virus a pandemic on $11^{\text {th }}$ March 2020. The virus then spread across the globe resulting in immediate and long-term effect on the health, social and economic status of countries and individuals, (World Health Organization, 2020). Kenya declared its first case on $13^{\text {th }}$ March 2020 and since then the cases steadily rose within the first 3 months of citing of the index case. This resulted in the government enforcing a series of preventive measures as recommended by the WHO. Amongst the measures enforced was the closure of all learning institutions, to ensure social and physical distancing was possible to contain the number of transmissions. Some of the learning institutions were then converted to quarantine centres with the aim of containing the disease. (Ministry of Eduction, 2020)

According to Jena (2020), COVID 19 significantly disrupted the education sector which is a determinant of a country's economic future. In Kenya 18 million learners were affected countrywide most of whom were still dependants of their parents and closure of schools meant they were staying at home. Since its declaration as a pandemic COVID 19 had affected different countries in different magnitude with management strategies differing significantly. At the time of this study there was no known vaccine nor effective treatment of COVID 19. Countries then moved to find strategies to adapt and live with this disease in a bid to resume to the new normal as urged by the WHO during its $73^{\text {rd }}$ World health assembly.

United Nations Educational Scientific and Cultural Organization (2020) also urged countries to allow resumption of institutional learning considering that school based learning brought other benefits to learners such as social and nutritional benefits and not just the academic benefits. Bryant, Dorn, Hall and Panier, (2020) acknowledged that the dilema in reopening remained, whether it would lead to re emergence of the virus among students, staff and community members.Timelines for reopening were dependant on four interelated factors including risks to public health, schools importance to economic recovery, the impact of education and their readiness.

Readiness of parents may be largely affected by knowledge and management of COVID 19 pandemic. Its effect on the mental health of parents and teachers can determine whether they wanted to allow students resume to face to face classes. The return of students to face to face learning posed a large challenge as the mesosystem needed adapt to a 'new normal'that is: having face masks on correctly at all times, frequent hand hygiene, ensuring social distance and generally being concious of the environment to avoid contagion, (Abad \& Abad, 2020)

\section{Problem Statement}

COVID 19 has been seen to be highly infectious causing several deaths amongst citizens worldwide. This has resulted in an increase in anxiety and fear in the public. Despite all efforts made to manage the disease, it has been realized that people must learn to live with the disease as the experts try to find treatment or a vaccine. In Kenya, many learning institutions were converted temporarily to quarantine centers, and their facilities used by contacts of COVID 19 clients. According to Obordo (2020), parents like the rest of the citizens have experienced the 
Journal of Health, Medicine and Nursing

ISSN 2520-4025 (Online)

Vol.5, Issue 5. No.4, pp 44- 50, 2020

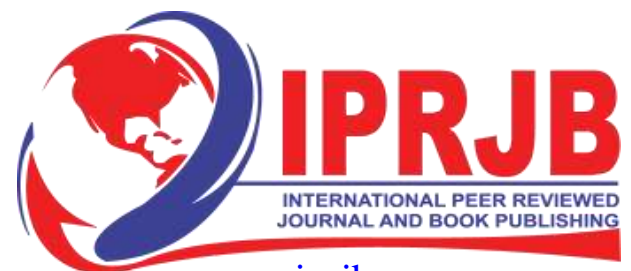

wWw.iprib.org

effects of the pandemic and care for the wellbeing of their children when it comes to resumption of normal activities. Resumption of normalcy includes return of face to face learning. The general concern of safety coupled with the college's facilities being used as a quarantine centre may result in an increase in anxiety among parents and delay their readiness to allow students back in college. It is therefore important to assess readiness of parents to allow students resume college to ensure key decisions affecting students are not based on assumptions.

\subsection{METHODOLOGY}

The study was a descriptive cross-sectional design done at KMTC-Mombasa Campus. Participants (guardians) were selected using multistage convenient random sampling method, where an assumption of each student having at least one parent was made. The total population of students is $850,10 \%$ of the student population was found to be a representative number for parents. $(0.1 \times 850), n=85$ with a confidence level of $95 \%$. Response rate was $85.8 \%(n=73)$. Data was obtained using interviewer administered questionnaires. Data analysis was done using SPSS and excel then results were presented using tables and narrations.

\subsection{RESULTS}

\subsection{Demographics of respondents}

\section{Table 1: Demographics of participants}

\begin{tabular}{clrr}
\hline Demographics & Category & Frequency $(\mathbf{n}=73)$ & Percentage \\
\hline & & & \\
& 30-39 years & 4 & 5.5 \\
\multirow{3}{*}{ Age (years) } & 40-49 years & 25 & 34.2 \\
& 50-59 years & 30 & 41.1 \\
& 60 years and above & 14 & 19.2 \\
& Total & 73 & 100 \\
& Male & 40 & 54.8 \\
\multirow{2}{*}{ Gender } & Female & 33 & 45.2 \\
& Total & 73 & 100 \\
\hline
\end{tabular}

In this study parents were defined as, the person taking the parental role of the student that is, one who can take care of the welfare of the students. Table 1.0 shows $41.1 \%$ (30) parents were aged between 50 to 59 years with only $5.5 \%$ (4) aged between 30-39 years. Gender in this study was defined as the biological sex assigned at birth. $54.8 \%$ (40) of parents were male while 45.2 $\%$ (33) were female. These findings are consistent with a study conducted by Lago-Ballesteros, Martins, Gonzalez-Valerio and Ferna' ndez-Villarino (2019) showed a similar distribution of both age and gender in parents' population of students in higher learning institutions. In Africa, most cultures are patriarchal, and the fathers are expected to be the ones with an income while the women are homemakers. It is possible that like most African cultures Kenyan students indicate their primary guardian as the father because of this culture. 
Journal of Health, Medicine and Nursing

ISSN 2520-4025 (Online)

Vol.5, Issue 5. No.4, pp 44- 50, 2020

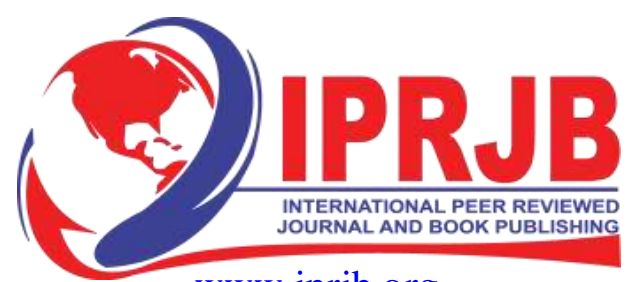

WWW.iprjb.org

3.2 Readiness of guardians to allow students resume college after its use as a quarantine centre

In this study readiness was defined as the willingness of parents to allow their children to resume institutional learning. Readiness was included in the study to evaluate the ability of parents to allow their children to go back to college. Parents were asked how soon they were willing to allow students resume college, "immediately" meaning parents would allow students go back to college at the time of data collection and "later" meaning parents were reluctant to allow students resume college immediately collection

Table 2: Readiness of Parents to allow students resume to college

$\begin{array}{lll}\text { Readiness of guardians } & \text { Frequency }(n=73) & \text { Percentage }\end{array}$

\begin{tabular}{lcc}
\hline Immediately & 57 & 78 \\
Later & 16 & 22 \\
Total & 73 & 100 \\
\hline
\end{tabular}

Table 2 shows $78 \%$ (57) parents were willing to allow students go back to college while $22 \%$ of parents were reluctant to allow students go back to college. This implied that parents were ready to allow students resume face to face learning.

\subsection{Awareness and readiness to allow students resume college}

Awareness was defined as parents having the knowledge of college being used as a quarantine center. Respondents were asked if they were aware that the campus was being used as a quarantine center and were required to indicate a yes or no.

Table 3: Awareness and readiness to allow students back to college

$65.8 \%$ (48) parents were aware of the college being used a quarantine center whereas $34.2 \%$ (25) respondents were unaware. $81 \%$ (39) parents of those who were aware that the college had been converted to a quarantine center were willing to allow students go back to college. This implied that awareness of the college's temporary conversion to a quarantine center did not affect the readiness of parents to allow the students go back to college $(\mathrm{p}=0.365)$

\subsection{Perception of Safety and readiness to allow students back to college}

Perception of safety meant the students would be free from acquiring infection once they resumed. Perception of safety was included in the study as it is a key determinant of readiness, as outlined by (Abad \& Abad, 2020). Participants were asked if they felt comfortable allowing their students resume college following its use as a quarantine center by stating yes or no.

Table 4: perception of safety and readiness to allow students go back to college

\begin{tabular}{llll}
\hline Perception of Safety & Readiness & Total \\
Yes & Immediately & Later & \\
No & 57 & 10 & 67 \\
Total & 0 & 6 & 6 \\
\hline
\end{tabular}


Journal of Health, Medicine and Nursing

ISSN 2520-4025 (Online)

Vol.5, Issue 5. No.4, pp 44- 50, 2020

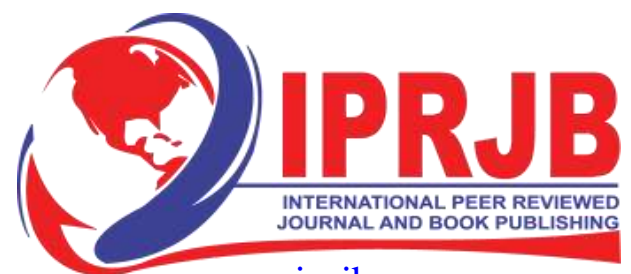

WWW.iprjb.org

92\% (67) parents perceived the college as safe despite its use as a quarantine center, while $8 \%$ of the parents termed the college unsafe. $85 \%$ (57) of those who perceived the college as safe were willing to allow their children resume college immediately whereas $15 \%$ (10) were reluctant to allow students resume immediately.8\% (6) parents who perceived the college as unsafe were all reluctant to allow students resume college. Perception of safety had a significant effect on the readiness to allow students resume college $(\mathrm{p}=0.001)$. This implied that if parents perceived the college unsafe, they would be reluctant to allow students resume college.

\subsection{DISCUSSION, CONCLUSIONS AND RECOMMENDATIONS}

COVID 19 pandemic resulted in disruption of face to face learning globally. The disease was found to be spreading amongst humans when they had close contact with each other through air droplets, (WHO, 2020). As part of containment measures, on $15^{\text {th }}$ March 2020 the government of Kenya shut down learning institutions to contain infection rates, affecting 18 million learners as reported by MOE (2020) converting some to quarantine centers. KMTC was among the institutions converted to quarantine centers. The closure of schools resulted in a transition to online and distance learning by some institutions to comply with government directives. Remote learning has not been accessible and affordable to all; thus, its implementation has equally had its challenges resulting in educational inequities, (UNESCO, 2020). Kenya in response to the UNESCO report developed protocols and guidelines to ensure safe reopening of schools and access for all, (MOE, 2020). Resumption of institutional learning means students going back to their facilities which were used as quarantine centers during the pandemic, this study explored the readiness of parents as key stakeholders to release students to resume college.

In this study $78 \%$ (57) parents were willing to allow their children resume to college despite its use as a quarantine center. According to UNESCO the decision to allow schools to reopen positively impacts on child health, family income and overall economy. The greatest benefit for reopening is to reduce the risk of school dropout allowing students to finish school whereas having their children at home increases the economic burden. Having college students resume school is burden lifted off their parents back. In Kenya, the Higher Education Loans Board (HELB) disburses funds to support students' upkeep and fees, (Malechwanzi, Shen, and Mbeke, 2016). During the pandemic, these funds have not been accessible to students. Students find a way of supporting themselves by using these funds as capital and supporting their parents back home. This could be the reason as to why parents were eager to allow their children resume college immediately.

$81 \%$ (39) of parents who were aware that the college was being used as a quarantine center were ready to allow students resume college. It implied that the decision to convert college facilities to a quarantine centre did not affect the willingness of parents to allow students back to college $(\mathrm{p}=0.365)$. In Kenya, some institutions transitioned to online learning, this strategy of teaching was effective for parents who could afford the resources needed for its implementation however it did not reach the needs of those who could not afford. This could have been the reason why these parents wanted their children back in college at least then the parents were sure that their children had access to education and were exposed to similar experience as their colleagues. This can be related to findings by Teach to vote (2020) as reported in the USA where parents with higher income felt more ready to handle remote learning than parents with lower income who 
Journal of Health, Medicine and Nursing

ISSN 2520-4025 (Online)

Vol.5, Issue 5. No.4, pp 44- 50, 2020

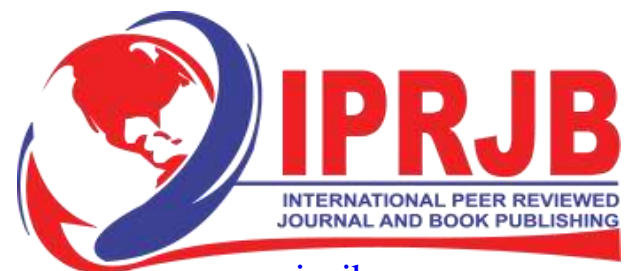

WWW.iprjb.org

felt unprepared for remote learning. These findings also correspond to Amanor-Mfoafo, Akrofi, Edonu and Dowuona, (2020) who reported that $15.92 \%$ of parents did not support the use elearning and that they felt more comfortable with face to face. In addition, Onyema et al (2020) reported that online learning in developing countries faced challenges such as network connectivity, constant power outages' poor digital skills among others

Parents perception of safety largely affected their readiness to allow students resume college, ( $\mathrm{p}=0.001) .92 \%$ (67) of parents perceived college as safe, of these, 85\% (57) would allow their children to resume college immediately. However, all the $8 \%$ (6) of the parents who perceived college as an unsafe environment for the students to resume would allow them to resume later. These findings concur Education dive (2020) where 89\% of parents stated that the level of safety measures implementation by a school regarding COVID19 affected their readiness to allow students resume college. Level of safety was a major concern because parents stated that they are likely to change schools if safety measures are not adhered to. According to Abraham Maslow's hierarchy of needs after physiological needs, safety and security is a fundamental human need. Kenyan parents feel the need to provide safety to students even when the responsibility to provide safety for their children is out of their control. $92 \%$ of parents felt safe thus their readiness to allow students to resume immediately. The government of Kenya has been in the forefront in advocating for implementation of safety measures across schools and campuses countrywide as well as giving guidelines to schools and colleges on safe reopening. This countrywide publicity and communication on the Ministry of Education preparedness may have played a key role in positively influencing the perception of safety further influencing their readiness to allow students go back to school. Parents had resumed some form of normalcy this may have also impacted their decision to allow students resume college.

\section{Conclusions}

In conclusion most parents were ready to allow students resume college immediately. The use of college facilities as a quarantine centre had not altered their willingness to allow students resume college. Prior to the pandemic college facilities seemed sufficient to for learning. However, with the new pandemic protocols and requirements for prevention of transmission of COVID 19 there is need for adjustment to meet the required standards. The management started plans to implement COVID mitigation strategies within college to ensure safety of learners once they resume college.

\section{Recommendations}

Communication on mitigation measures instituted by the college to parents is key to increase their perception of the college as safe, this will increase the level of readiness for parents to allow students resume college. Stakeholders in the education sector must increase strategies in preparation for reopening as parents are ready to release students resume College.

\section{REFERENCES}

1. Abad A., and Abad T. M., July 2020: Back to school after Covid-19 lockdown in Brazil.

2. Amanor-Mfoafo N., Akrofi O., Edonu K., and Dowuona E. (2020). INVESTIGATING THE E-LEARNING READINESS OF GHANAIAN PARENTS DURING COVID19. European journal of Educational studies, 7(Issue 10). www.oapub.org/edu 
Journal of Health, Medicine and Nursing

ISSN 2520-4025 (Online)

Vol.5, Issue 5. No.4, pp 44- 50, 2020

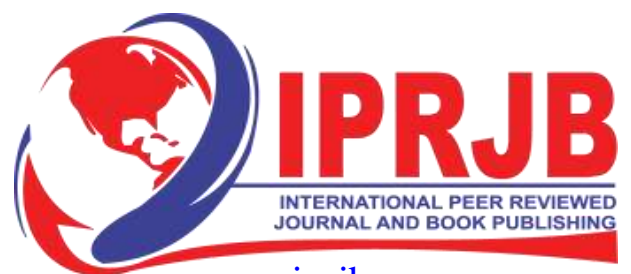

WWW.iprib.org

3. Bryant J., Dorn E., Hall S. and Panier F., April 2020: Safely back to school after coronavirus closures. https://www.mckinsey.com/industries/public-and-social-sector/ourinsights/safely-back-to-school-after-coronavirus-closures\#

4. Education, M. of. (2020). Kenya_basic_Education_COVID19_Emergency_Response_Plan-compressed.pdf. retrieved from https://www.education.go.ke/index.php/downloads

5. Education Dive. Survey reveals parents' top concerns about returning to school since COVID-19. (n.d.). Education News Dive. https://www.educationdive.com/press-release/20200615-survey-reveals-parentstop-concerns-about-returning-to-school-since-covid-

6. Jena P. K., July 2020: Impact of Pandemic COVID-19 on Education in India. Retrieved https://www.researchgate.net/profile/Pravat_Jena3/publication/342123463_Impact_of_Pa ndemic_COVID-19_on_Education_in_India/links/5f328b4c458515b7291590ff/Impactof-Pandemic-COVID-19-on-Education-in-India.pdf

7. Lago-Ballesteros J., Martins J., Gonzalez-Valerio $M$ and Ferná ndez-Villarino MA. (2019) Parental assessment of physical education in the school curriculum: A brief report on the influence of past experiences as students, PLosONE. doi: https://doi.org/10.1371/journal.pone.0219544.t001

8. Malechwanzi J. M., Shen H., and Mbeke C., 2016: Policies of access and quality of higher education in China and Kenya: A comparative study. Retrieved https://www.tandfonline.com/doi/full/10.1080/2331186X.2016.1201990?src=recsys

9. Obordo R. (May 2020). The Guardian. Rushed and Premature: Parent reveal fears over schools reopening amid COVID-19 crisis. https://www.theguardian.com/education/2020/may/15/rushed-and-premature-parentsreveal-fears-over-schools-reopening-amid-covid-19-crisis

10. Onyema E.M., Eucheria C.N., Obafemi A., Sen S., Atonye F.G., Sharma A and Alsayed A (2020). Impact of Coronavirus Pandemic on Education. (2020). Journal of Education and Practice. https://doi.org/10.7176/jep/11-13-12

11. UNICEF, August 2020: What will a return to school during the COVID-19 pandemic look like? https://www.unicef.org/coronavirus/what-will-return-school-during-covid-19pandemic-look

12. UNESCO Digital Library. (n.d.). Retrieved from https://unesdoc.unesco.org/search/NEXPLORE-6a97d0ae-7e33-4a8b-91ab-c7c74bc14226

13. Teach the Vote. (2020). Surveys illuminate parent and teacher worries in light of COVID-19. https://www.teachthevote.org/news/2020/05/27/surveys-illuminate-parentand-teacher-worries-in-light-of-covid-19/

14. World Health Organization. (September 11, 2020) Historic health assembly ends with global commitment to COVID-19 response. WHO.from https://www.who.int/newsroom/detail/19-05-2020-historic-health-assembly-ends-with-global-commitment-tocovid-19-response 